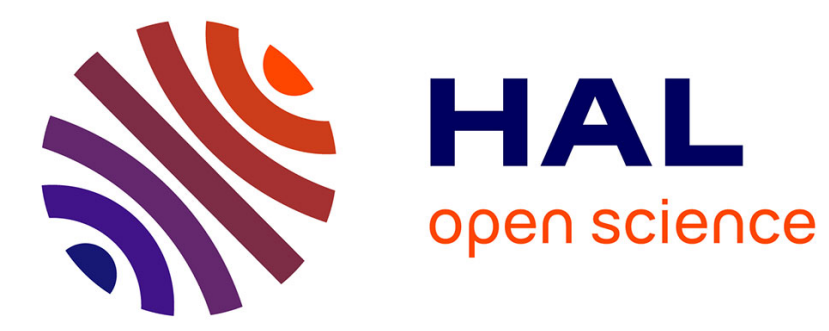

\title{
Probing the hydrolytic reactivity of 2-difluoromethyl pyrroles
}

\author{
Jennifer A. Melanson, Carlotta Figliola, Deborah A. Smithen, Aleksandra K. \\ Kajetanowicz, Alison Thompson
}

\section{> To cite this version:}

Jennifer A. Melanson, Carlotta Figliola, Deborah A. Smithen, Aleksandra K. Kajetanowicz, Alison Thompson. Probing the hydrolytic reactivity of 2-difluoromethyl pyrroles. Organic \& Biomolecular Chemistry, 2016, 15 (1), pp.144-152. 10.1039/C6OB01441K . hal-01588447

\section{HAL Id: hal-01588447 https://hal.science/hal-01588447}

Submitted on 15 Sep 2017

HAL is a multi-disciplinary open access archive for the deposit and dissemination of scientific research documents, whether they are published or not. The documents may come from teaching and research institutions in France or abroad, or from public or private research centers.
L'archive ouverte pluridisciplinaire HAL, est destinée au dépôt et à la diffusion de documents scientifiques de niveau recherche, publiés ou non, émanant des établissements d'enseignement et de recherche français ou étrangers, des laboratoires publics ou privés. 


\title{
Probing the Hydrolytic Reactivity of 2-Difluoromethyl Pyrroles
}

Jennifer A. Melanson, Carlotta Figliola, Deborah A. Smithen, Aleksandra K. Kajetanowicz and Alison Thompson*

Department of Chemistry, Dalhousie University, P.O. Box 15000, Halifax, NS, B3H 4R2, Canada

Alison.Thompson@dal.ca

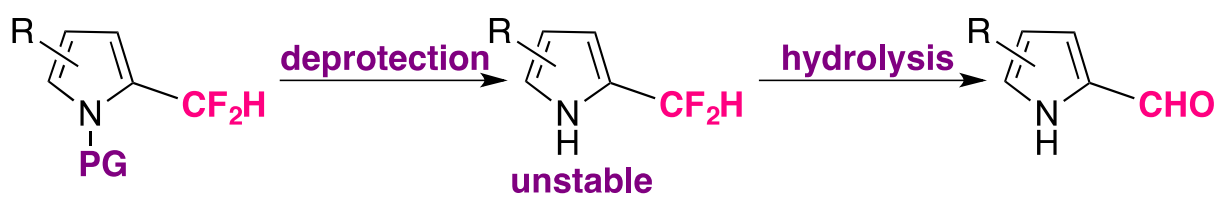

\begin{abstract}
Difluoromethyl pyrroles were found to be stable while $N$-protected with an electronwithdrawing group. Due to the propensity of pyrroles to access azafulvenium-like intermediates, the C$\mathrm{F}$ bonds of an $\alpha$-difluoromethyl substituent are labile under hydrolytic conditions. The presence of certain electron-withdrawing substituents about the pyrrolic ring can accelerate this process, as determined through a kinetic comparison of the deprotection and subsequent hydrolysis reactions of $N$ protected $\beta$-aryl $\alpha$-difluoromethyl pyrroles.
\end{abstract}

\section{Introduction}

Porphyrinogens have been intensely studied, particularly as regards to chemical and biological relevance of the corresponding porphyrins. ${ }^{1-4}$ Although spontaneous oxidation of porphyrinogens to porphyrins can render the isolation of these precursors rather challenging, ${ }^{5}$ calix [4]pyrroles ${ }^{6}$ bear eight alkyl or aryl groups at the meso positions of the tetrapyrrolic skeleton and thus resist oxidation. ${ }^{7-14}$ The presence of a meso $\mathrm{sp}^{3}$ carbon confers to the structure a significant conformational freedom, ${ }^{5}$ enabling potential binding of these macrocycles for a wide range of applications. ${ }^{7-14}$ As part of an ongoing effort to develop functionalised dipyrrolic structures, we began to investigate the synthesis of pyrroles featuring a $-\mathrm{CF}_{2}$ - moiety at the $\alpha$-position, contrasting with the $-\mathrm{CR}_{2}$ - unit $(\mathrm{R}=$ alkyl or aryl $)$ used as precursors to calix[4]pyrroles. The strength of the $\mathrm{C}-\mathrm{F}$ bond, ${ }^{15}$ alongside its ability to sterically mimic 
the $\mathrm{C}-\mathrm{H}$ unit, has driven growing interest in the use of fluorine as an isostere of hydrogen, a common strategy in agrochemical ${ }^{16}$ and pharmaceutical industries. ${ }^{17,18}$ In tandem, the development of more efficient and diverse methods through which to incorporate this functional moiety, either directly ${ }^{19-22}$ or via the fluorination of existing functionality, ${ }^{23}$ renders this group even more suitable for incorporation into a wide variety of frameworks. However, there are few reports describing pyrroles bearing a difluoromethyl substituent directly appended to the heterocyclic core. Baran and co-workers developed a fluorinating reagent for the installation of a difluoromethyl group on nitrogen-containing heteroaromatic compounds via a radical mechanism (Scheme 1, top): ${ }^{19} \mathrm{~N}$-unsubstituted 2- and 3-acyl pyrroles 1a-b were shown to react promptly with ZnDFMS in the presence of $t \mathrm{BuOOH}$ and gave the $\alpha$ difluoromethyl-substituted analogues $\mathbf{2 a - b}$ in moderate yield. Note that $\mathbf{2 a}$ and $\mathbf{2 b}$ both feature conjugated electron-withdrawing acyl groups that serve to stabilise the heterocylic core. 


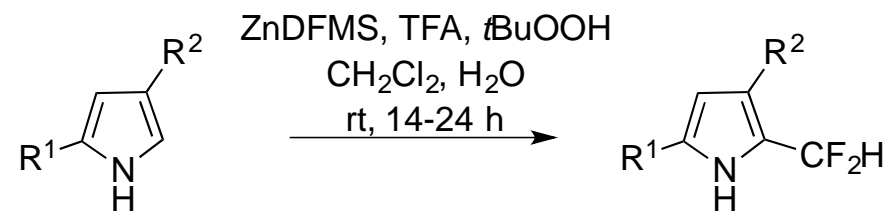
1a $: \mathrm{R}^{1}=\mathrm{COMe}, \mathrm{R}^{2}=\mathrm{H}$
2a : $55 \%$
1b : $R^{1}=H, R^{2}=$ COMe
$2 b: 65 \%$

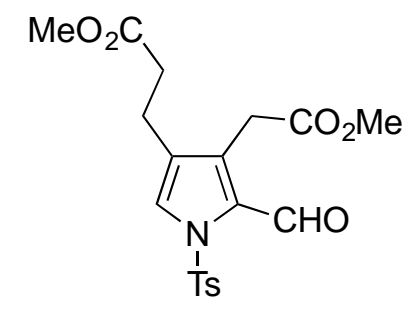

3

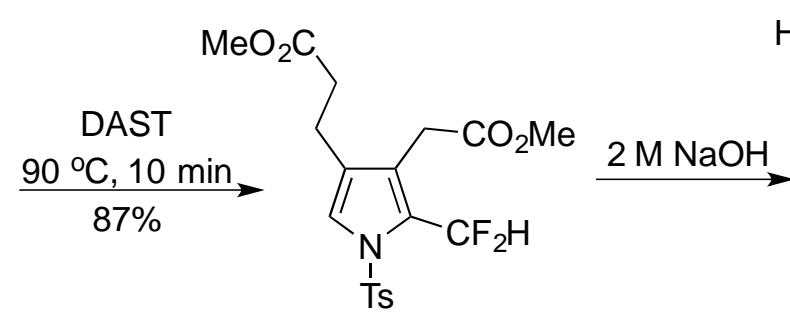

4<smiles>O=C(O)CCc1c[nH]c(C(F)(F)F)c1CC(=O)O</smiles>

5

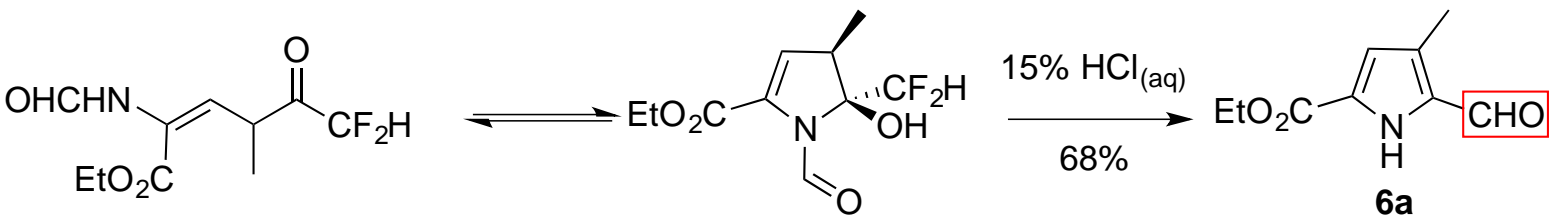<smiles>CCOC(=O)/C(=C\CC(=O)C(F)(F)F)NC=O</smiles>

Scheme 1. Examples of $\alpha$-difluoromethyl-substituted pyrroles.

In 1995 Scott reported the fluorination of several 2-formyl pyrroles using DAST, with the goal of synthesising an inhibitor of the uroporphyrinogen III cosynthase. ${ }^{24}$ Pyrrole $\mathbf{3}$, which features a substitution pattern matching that of the enzyme substrate, uroporphomethene, reacted with DAST to render 4 in high yield (87\%, Scheme 1, middle). Subsequent deprotection of 4 under standard hydrolysis conditions was reported to give the desired $\alpha$-difluoromethyl pyrrole $\mathbf{5}$ apparently without loss of fluorine. However, experimental conditions or isolated yields for this step are not described, nor does the report include any evidence for the stated maintenance of fluoro substituents. As reported by Haufe (Scheme 1, bottom) ${ }^{25}$ upon exposure to acid the stability of the difluoromethyl group is strongly 
influenced by the electronic nature of ring substitution. Indeed, in the presence of the electron-donating methyl group the difluoromethyl group was hydrolysed to the corresponding 2-formyl pyrrole 6a, while, under the same reaction conditions, pyrrole $\mathbf{6 b}$ was reported to be stable (Scheme 1). With the backdrop of these limited reports, we report herein upon the reactivity of $\alpha$-difluoromethyl pyrroles under hydrolytic conditions, ${ }^{24}$ as well as an approach for the preparation of $\beta$-aryl- $\alpha$-difluoromethyl pyrroles. Furthermore, the influence of the pyrrolic ring substitution pattern upon the reactivity of the $\alpha$-difluoromethyl functional group is discussed.

\section{Results and discussion}

The procedure for the synthesis of pyrrole 5 was repeated according to Scott's method (Scheme 1, middle). ${ }^{24}$ However, upon $\mathrm{N}$-deprotection of $\mathbf{4}$ the isolated product corresponded to the $N$-unprotected aldehyde 8 (75\%, Scheme 2), with the two pendant esters of course hydrolysed to the corresponding carboxylic acids. As this result clearly contradicts the literature report, ${ }^{24}$ the reaction was repeated in deuterated solvents and progress was followed via ${ }^{1} \mathrm{H}$ and ${ }^{19} \mathrm{~F}$ NMR spectroscopic analysis. The initial $N$-deprotection of the $\alpha$-difluoromethyl pyrrole 4 was determined to occur immediately upon addition of $2 \mathrm{M} \mathrm{NaOH}$. The $N$-deprotected product 5 is unstable under these reaction conditions, forming first the $\alpha$-dimethylacetal pyrrole 7 which then hydrolyses to the $\alpha$-formyl pyrrole 8 (Scheme 2 and Figure 1 in the Supplementary Information).
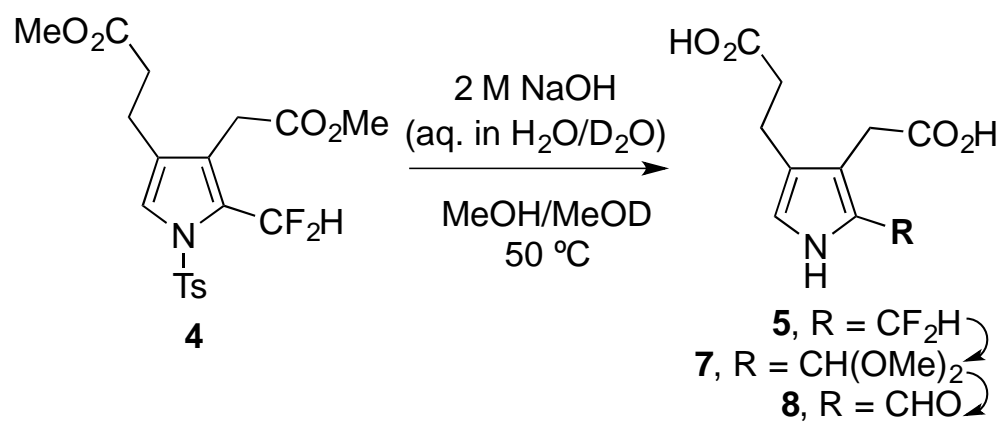

Scheme 2. $N$-deprotection and hydrolysis of pyrrole bearing a 2-difluoromethyl group. 
In order to exclude the possibility that the two alkanoate moieties influence the hydrolytic reactivity of the $\alpha$-difluoromethyl group, the unsubstituted variant $\mathbf{1 0}$ was exposed to the same conditions. ${ }^{26}$ Xtalfluor-M ${ }^{\circledR}$ was used to fluorinate the 2-formyl pyrrole 9, giving the $\alpha$-difluoromethyl pyrrole 10 in high yield $(90 \%$, Scheme 3$)$. The use of a stabilising $N$-protecting group proved essential for the fluorination reaction to be successful. To study the $N$-deprotection, aliquots from the reaction of 10 with $2 \mathrm{M}$ aqueous $\mathrm{NaOH}$ in $\mathrm{MeOD}$ at $50{ }^{\circ} \mathrm{C}$ were analysed using ${ }^{1} \mathrm{H}$ and ${ }^{19} \mathrm{~F} \mathrm{NMR}$ spectroscopy. As observed previously for $\mathbf{4}$, the rapid appearance of the $N$-unprotected material 11 was followed by methoxide displacement of the fluoro substituents, to give the acetal 12, which hydrolysed to the aldehyde 13 (Scheme 3 and Figure 2 in Supporting Information).

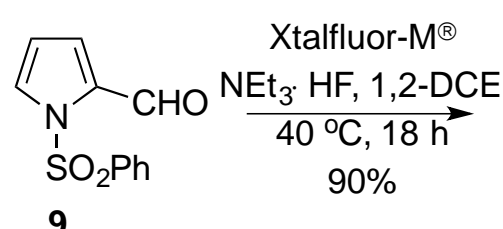

9

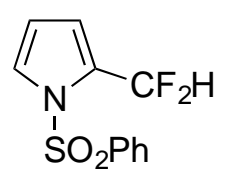

10

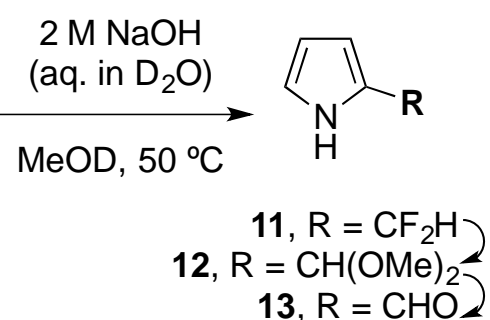

13, $\mathrm{R}=\mathrm{CHO}$

\section{Scheme 3: Formation and hydrolysis of $\alpha$-difluoromethyl pyrrole 11.}

Although some $N$-unprotected $\alpha$-difluoromethyl pyrroles featuring electron-withdrawing substituents on the heterocycle are stable (Scheme 1), ${ }^{19}$ such systems are clearly different to pyrroles such as $\mathbf{5}$ and 11, whereupon hydrolysis to result in loss of fluorine is facile. In order to investigate the influence of the electronic properties of substituents about the pyrrolic ring upon the deprotection and hydrolysis reactions, a series of $N$-(2-nosyl)- $\beta$-aryl-substituted pyrroles were synthesised. Moving away from the tosyl and $-\mathrm{SO}_{2} \mathrm{Ph}$ protecting groups, the 2-nosyl group was selected thus enabling the $N$ deprotection to be monitored via release of 2-nitrophenyl phenyl sulfide (14, Scheme 4). ${ }^{27,28}$ Moreover, $N$-deprotection of the 2-nosyl group would be achieved under anhydrous conditions. However, despite 2,4-dinitrophenol (2,4-DNP) being commonly used as a reporter for measuring reaction rates, we were unable to find reports of monitoring reaction rates through detection of yellow 2-nitrophenyl, 4- 
nitrophenyl or 2,4-dinitrophenyl phenyl sulfides. Furthermore, although 2-nitrophenyl phenyl sulfide is known, ${ }^{29-31}$ full characterisation proved elusive in the literature. Compound $\mathbf{1 4}$ was, therefore, prepared via deprotection of $\mathbf{1 5}$ using $\mathrm{PhSH}$ and $\mathrm{NEt}_{3}$. The ejected sulfide $\mathbf{1 4}$ was isolated in quantitative yield (Scheme 4), thereby demonstrating that this anhydrous method is viable for the needed $N$-deprotection of $N$-(2-nosyl) pyrroles. ${ }^{27,28,32}$ The absorption maximum of $\mathbf{1 4}$ occurs at $368 \mathrm{~nm}\left(\mathrm{CH}_{3} \mathrm{CN}\right)$, with an extinction coefficient of $4000 \mathrm{~L} \mathrm{~mol}^{-1} \mathrm{~cm}^{-1}$.
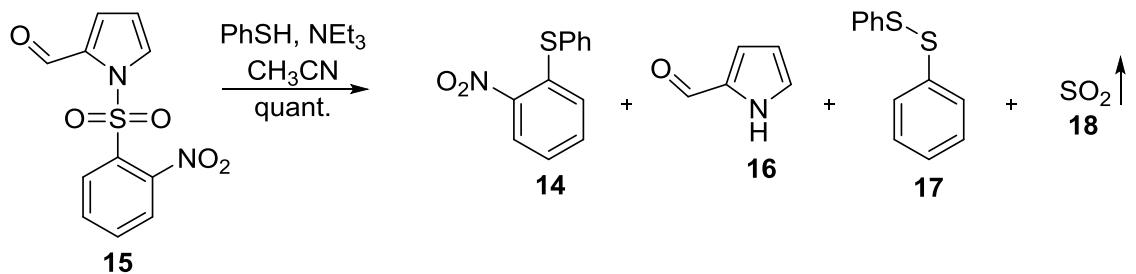

\section{Scheme 4. Synthesis of 2-nitrophenyl phenyl sulfide 14.}

$\alpha$-Difluoromethyl pyrroles 19a-f featuring various aryl groups at the $\beta$-position of the ring were synthesised according to Scheme 5. Suzuki coupling between $N$-(2-nosyl)-3-bromo-2-formyl pyrrole 20 and boronic acids a-f gave the corresponding $\beta$-aryl pyrroles 21a-f. Subsequent fluorination yielded the desired $\alpha$-difluoromethyl pyrroles 19a-f (Scheme 5).

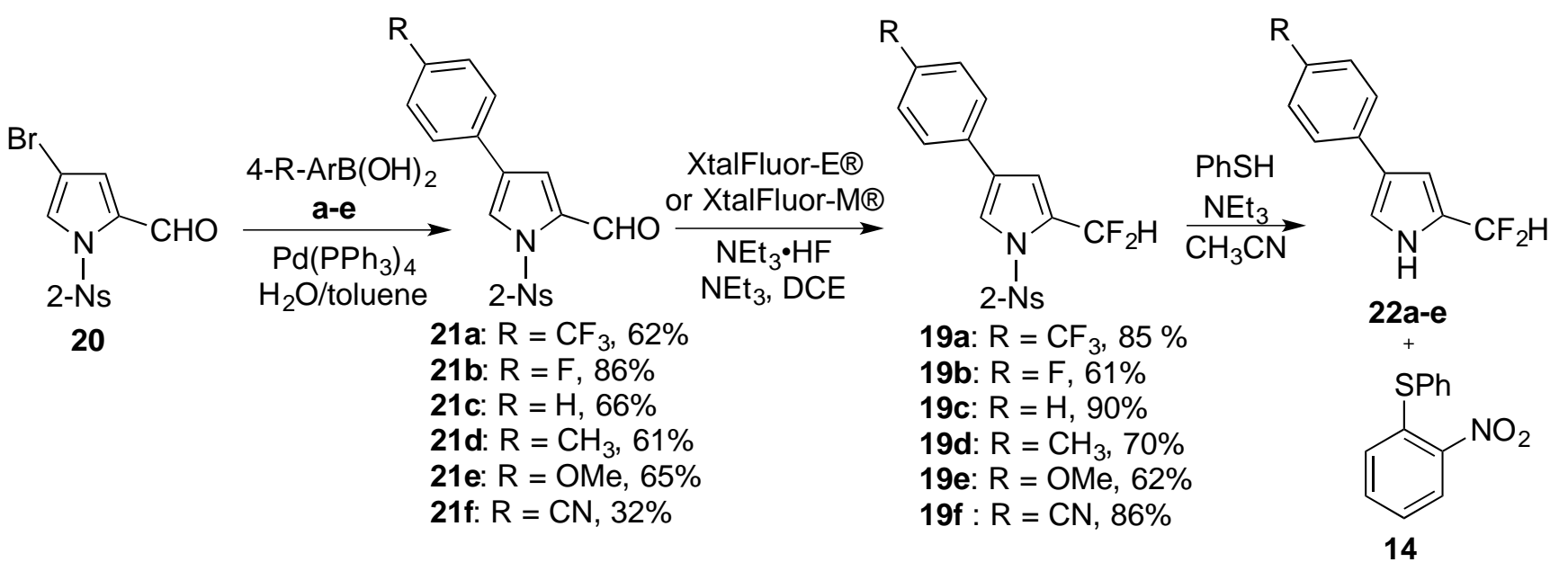

\section{Scheme 5: Synthesis of 22a-f.}


Upon $N$-deprotection of pyrroles 19 a-e with $\mathrm{PhSH}$ and $\mathrm{NEt}_{3}$ under anhydrous conditions, the resulting pyrroles (22a-e) proved to be stable providing the material remained under an inert and anhydrous environment (Scheme 5). As such, the deprotection and subsequent hydrolysis reaction could be studied separately. The first step was studied using UV-Vis spectroscopy under pseudo-first order conditions using 400 equivalents of $\mathrm{PhSH}$ and 560 equivalents of $\mathrm{NEt}_{3}$ in $\mathrm{CH}_{3} \mathrm{CN}$ at $0{ }^{\circ} \mathrm{C}$ under an inert atmosphere. Despite maintaining a steady flow of nitrogen gas in the sample chamber of the spectrophotometer, the presence of phenyl disulfide (17 in Scheme 4) was noted upon careful inspection of the reaction mixture arising from the $N$-deprotection of 19a-e. Several pathways to 17 may be at play during the reaction, e.g. thiophenol affords disulfide in the presence of an oxidising agent and a base $;^{33,34}$ the reaction by-product sulfur dioxide $\mathbf{1 8}$ acts as an oxidising agent. As the disulfide 17 also absorbs at $368 \mathrm{~nm}$, the absorbance reading at this ${ }^{35}$ wavelength is representative of both products. Since the interference from $\mathbf{1 7}$ is constant across the sample set, the relative production of 14 (Table 1, in Supporting Information) represents a qualitative estimation of the $N$-deprotection rate (Table 1). The starting materials provide no interference at the monitoring wavelength. The production of 14 was monitored via its absorbance at $368 \mathrm{~nm}$ (Table 1 in Supporting Information), and the relative rate constants of deprotection were thus calculated:

$$
\log \left(\frac{\mathrm{K}_{\mathrm{R}}}{\mathrm{K}_{\mathrm{H}}}\right)=\rho \sigma
$$

As shown in Table 1, the presence of electron-withdrawing character in the aryl substituent causes an increase in the rate of $N$-deprotection $\left(19 \mathbf{a}, \mathrm{R}=\mathrm{CF}_{3}\right)$. In contrast, electron-donating character $\left(\mathbf{1 9 e}, \mathrm{R}=\mathrm{OCH}_{3}\right)$ impedes the reaction rate. Fig. 1 shows a Hammett reaction constant $(\rho)$ of 0.4 , suggesting an increase of negative charge in the reaction intermediates. 
Table 1. Relative rate constants and Hammett parameters for the deprotection of 19a-e.

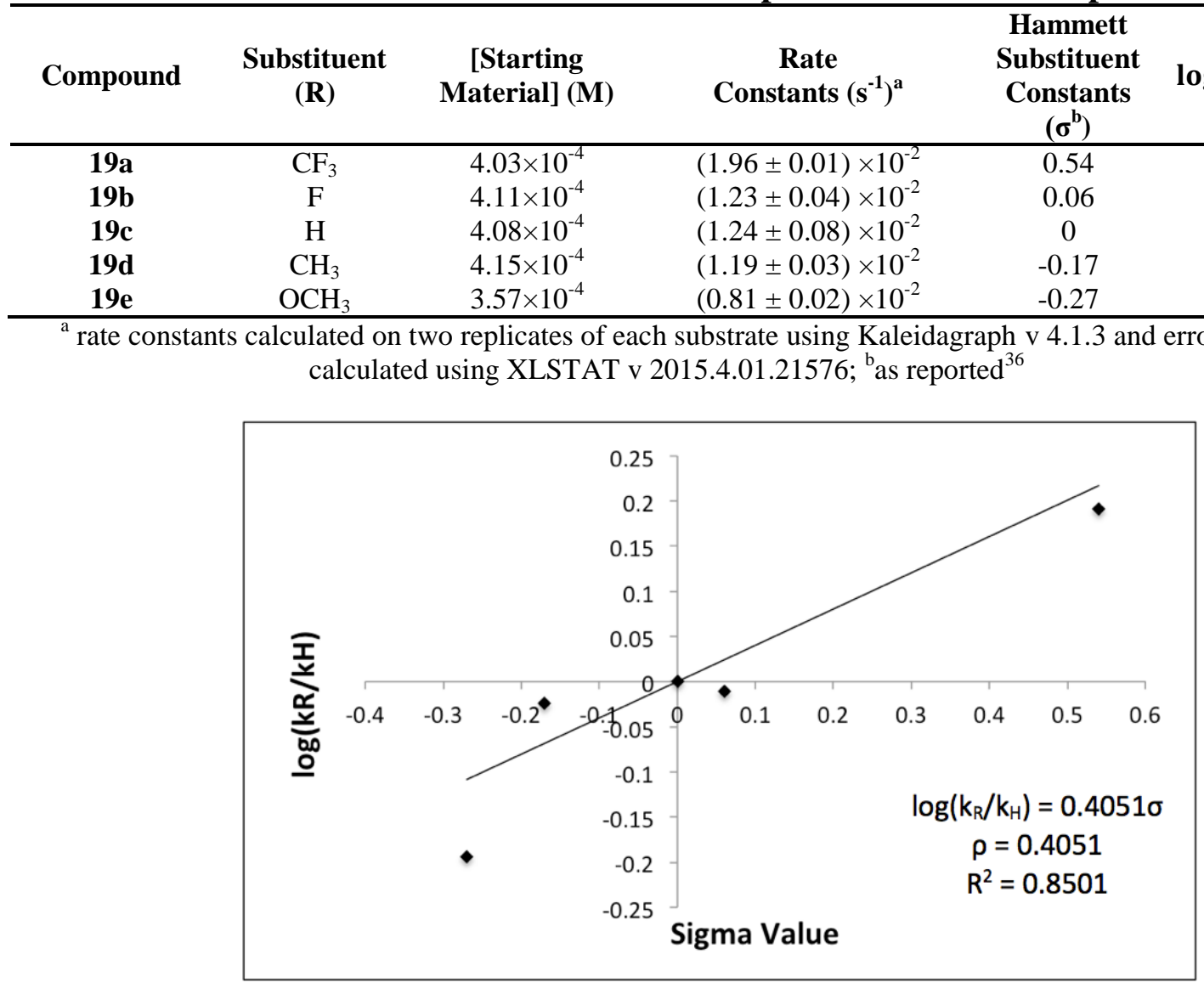

Fig. 1 Hammett plot for $N$-deprotection of 19a-e.

These features support the reaction mechanism proposed in Scheme 6. After nucleophilic attack by $\mathrm{PhSH},{ }^{37,38}$ the Meisenheimer-type intermediate $\mathbf{2 3}$ presumably collapses to give the reaction intermediate $\mathbf{2 4}$ and the development of anionic character in the orthogonal p-orbital of the pyrrolide nitrogen atom. ${ }^{27}$ The ability of the substituent (R) within the aryl group to stabilise the transition state leading to $\mathbf{2 4}$ thus plays an important role in the rate of deprotection. Indeed, electron-withdrawing groups serve to stabilize the forming pyrrolide anion, thereby enhancing the reaction rate, yet electronwithdrawing groups serve to destabilise the transition state en route to $\mathbf{2 4}$. As the electron-donating and electron-withdrawing R substituents are somewhat distant from the developing anionic nitrogen atom, their effects in stabilising the transition state are small and thus the $\rho$ value (Fig. 1) is small. 


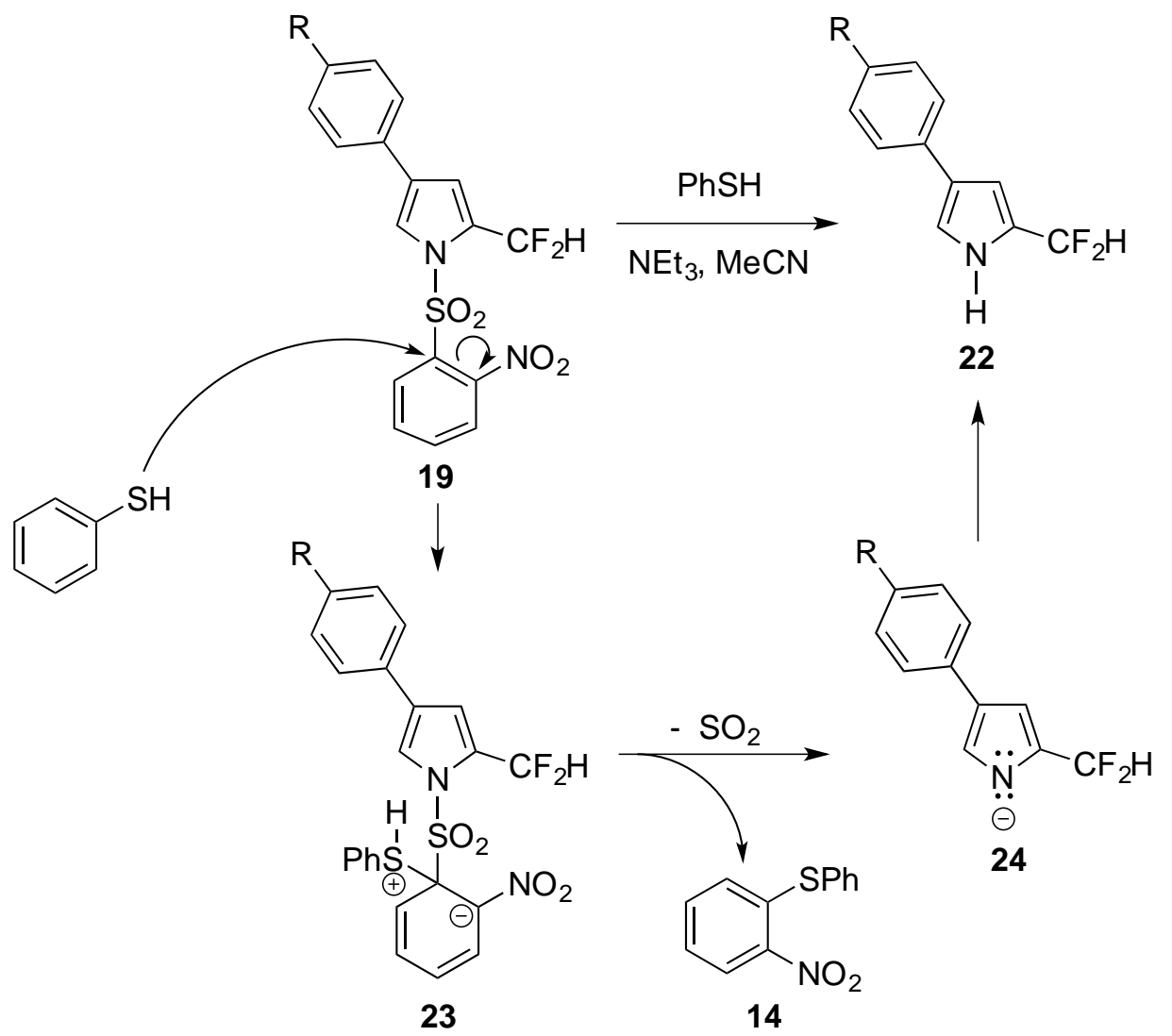

Scheme 6: Proposed mechanism for the $N$-deprotection of 19.

Having determined successful $N$-deprotection conditions, attention was turned to the hydrolysis of the $\alpha$-difluoromethyl group. Hydrolysis was monitored using ${ }^{19}$ F NMR spectroscopy under pseudo first-order conditions. Pyrroles 19 were first $N$-deprotected in an NMR tube using 1.8 equivalents of $\mathrm{PhSH}$ and 2.5 equivalents of $\mathrm{NEt}_{3}$, dissolved in $\mathrm{CD}_{3} \mathrm{CN}$. Subsequently, hydrolysis was initiated through the injection of 1000 equivalents of water at $40{ }^{\circ} \mathrm{C}$. As the hydrolysis reaction progressed, the decreasing intensity of the ${ }^{19} \mathrm{~F}$ doublet arising from the $-\mathrm{CF}_{2} \mathrm{H}$ group, with respect to the inert internal standard (hexafluorobenzene, 0.5 equiv., $0.4 \mathrm{M}$ solution in $\mathrm{CD}_{3} \mathrm{CN}$ ), was measured and the rates of hydrolysis calculated (Table 2). The disappearance of the $-\mathrm{CF}_{2} \mathrm{H}$ group signal in each case was accompanied by the expected appearance of the HF singlet, which derives from hydrolysis of the $\mathrm{CF}_{2} \mathrm{H}$ group (Figure 3-7 in the Supporting Information). 
Table 2. Rates and Hammett parameters for the hydrolysis of 22a-f.

\begin{tabular}{|c|c|c|c|c|c|}
\hline Compound & $\begin{array}{l}\text { Substituent } \\
\text { (R) }\end{array}$ & $\begin{array}{c}\text { [Starting Material }] \\
\mathbf{M}\end{array}$ & $\begin{array}{c}\text { Rate } \\
\text { Constant }\left(s^{-1}\right)^{a}\end{array}$ & $\begin{array}{c}\text { Hammett } \\
\text { Substituent } \\
\text { Constants } \\
\left(\sigma^{\mathbf{b}}\right) \\
\end{array}$ & $\log \left(\frac{K_{R}}{K_{H}}\right)$ \\
\hline $22 a$ & $\mathrm{CF}_{3}$ & $1.400 \times 10^{-2}$ & $(1.712 \pm 0.092) \times 10^{-3}$ & 0.54 & 0.27 \\
\hline $22 \mathbf{b}$ & $\mathrm{F}$ & $1.408 \times 10^{-2}$ & $(0.966 \pm 0.108) \times 10^{-3}$ & 0.06 & 0.02 \\
\hline $22 c$ & $\mathrm{H}$ & $1.501 \times 10^{-2}$ & $(0.914 \pm 0.094) \times 10^{-3}$ & 0.00 & 0.00 \\
\hline 22d & $\mathrm{CH}_{3}$ & $1.422 \times 10^{-2}$ & $(1.021 \pm 0.013) \times 10^{-3}$ & -0.17 & 0.05 \\
\hline $22 \mathrm{e}$ & $\mathrm{OCH}_{3}$ & $1.450 \times 10^{-2}$ & $(1.195 \pm 0.025) \times 10^{-3}$ & -0.27 & 0.12 \\
\hline $22 f$ & $\mathrm{CN}$ & $1.488 \times 10^{-2}$ & $(1.749 \pm 0.040) \times 10^{-3}$ & 0.66 & 0.28 \\
\hline
\end{tabular}

Although the variation in the rates of hydrolysis are subtle, the Hammett plot (Fig 2) resembles a concave up parabola with a minimum at $\mathrm{R}=\mathrm{H}(\mathbf{2 2 c})$. To confirm the concave up parabola, we synthesized and analysed $22 \mathrm{f}(\mathrm{R}=\mathrm{CN})$, following the same protocols as previously, and were delighted to observe an excellent fit with the data generated from 22a-22e. The non-linear relationship ${ }^{39,40}$ revealed on the Hammet plot points to the influence of the electronic features of the substituents on the aryl ring of pyrroles $\mathbf{2 2}$. The $\rho$ value for electron-donating groups was found to be -0.4 , suggesting a build-up of positive charge (or neutralisation of negative charge, negative slope, Fig 2). In contrast, the $\rho$ value for electron-withdrawing groups was found to be 0.4 , suggesting an increase of the negative charge character in the transition state of the rate-determining step (positive slope, Fig 2). 


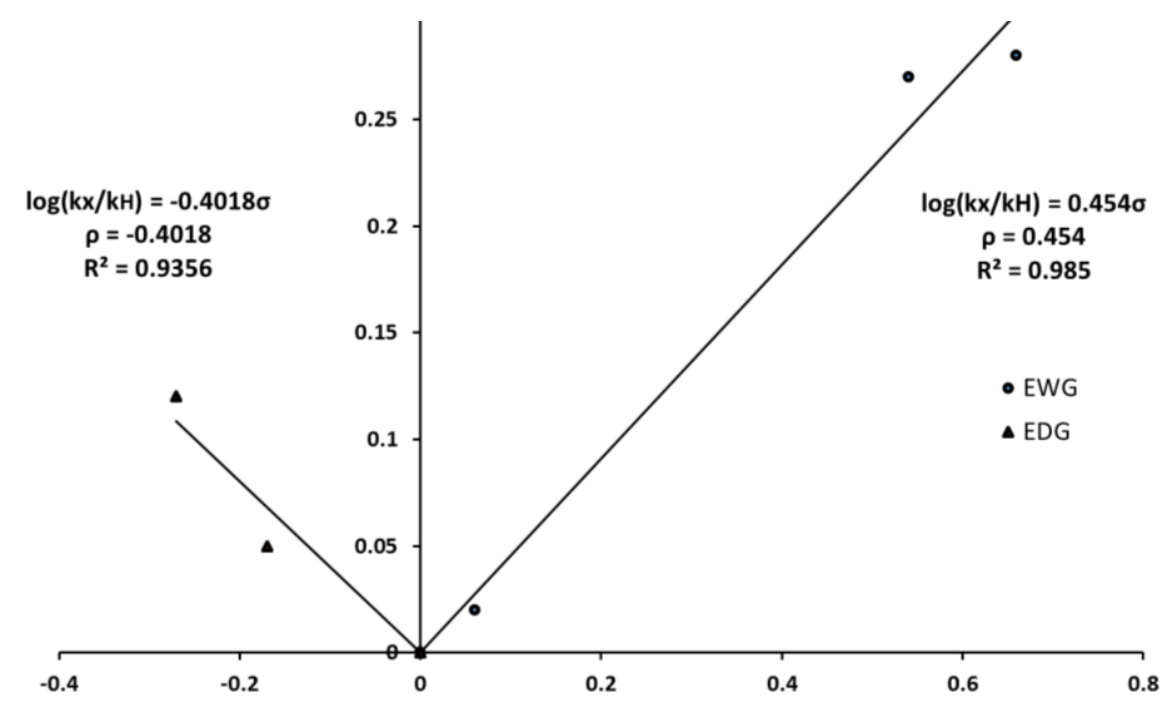

Fig 2 Hammett plot for the hydrolysis of 19a-f following $N$-deprotection.

Based on these results, and the concave up parabola of the Hammet plot, two competing reaction pathways are proposed for the hydrolysis of $\mathbf{2 2}$ (Scheme 7). In the case of $\mathrm{R}$ being an electrondonating group $\left(\mathrm{R}=\mathrm{CH}_{3}\right.$ and $\mathrm{OCH}_{3}$ ), the rate-determining step is considered to be the loss of fluoride and formation of the positively charged azafulvenium intermediate $\mathbf{2 5}$, whose methylene carbon atom is activated towards the fast addition of water and the return of aromaticity to the pyrrole ring in $\mathbf{2 6}$. ${ }^{41-44}$ After proton loss the intermediate $\mathbf{2 7}$ would collapse into the isolated aldehyde $\mathbf{2 9}$, again through loss of fluoride via azafulvenium formation. In the case of $\mathrm{R}$ being an electron-withdrawing group $(\mathrm{R}=$ $\mathrm{CF}_{3}, \mathrm{~F}$ and $\mathrm{CN}$ ) the generation of $\mathbf{2 5}$ would be slow, as appreciated upon consideration of the resonance contributor 29. In this case, loss of a proton, to form negatively charged pyrrolide 30, is proposed as the rate-determining step. The transition state en route to $\mathbf{3 0}$ would be stabilised by electron-withdrawing substituents on the aryl ring. Loss of fluoride would then generate the azaulvene 32, followed by addition of water to give 33. Proton exchange would provide 27, which would collapse into the isolated aldehyde 29, presumably again via initial pyrrolide formation and subsequent generation of the corresponding azafulvene. Akin to the $N$-deprotection step, as the electron-donating and electronwithdrawing substituents $(\mathrm{R})$ are somewhat distant from the developing azafulvenium and pyrrolide 
cores, their effects in stabilising the transition states are small and consistent with the small $\rho$ values (Fig. 1) for the two constituent slopes of the concave up parabola.

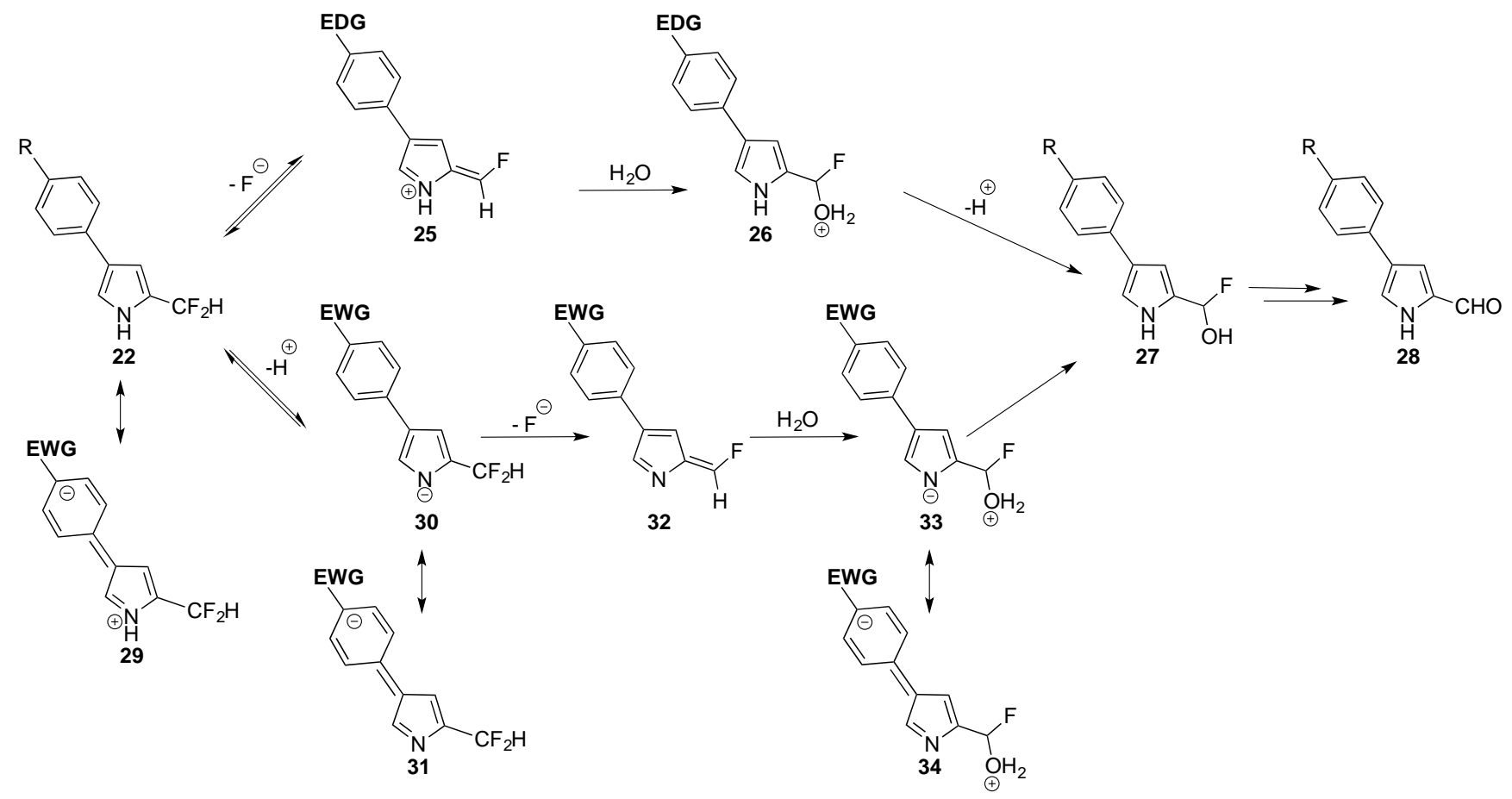

Scheme 7. Proposed mechanisms for the hydrolysis of 22.

To summarise, the tendency for $\alpha$-difluoromethyl pyrroles to react with water is significant, particularly in the absence of significant electron-withdrawing $N$-protection. As such, the electronic nature of substituents about $\alpha$-difluoromethyl pyrroles influences the reactivity, and hence the stability, of the $\alpha$-difluoromethyl group. Driven by azafulvenium formation, the loss of fluoride is facile, ${ }^{41}$ yet a significant electron-donating character on the pyrrolic ring serves to make azafulvenium character (via loss of fluoride) less favourable. In these cases, hydrolysis is proposed to rely upon $N$-deprotonation, followed by azafulvene formation via loss of fluoride. Therefore, the design of air-stable difluoromethyl pyrroles must consider the incorporation and positioning? of units with significant pyrrole stabilising ability, ${ }^{42-44}$ and/or electron-withdrawing capacity via $N$-protection, in order to avoid hydrolysis. 


\section{Comment re acyl?}

\section{Experimental}

\section{General information}

All ${ }^{1} \mathrm{H}$ and ${ }^{13} \mathrm{C}$ NMR spectra were obtained using a $500 \mathrm{MHz}$ NMR spectrometer (operating at 500 $\mathrm{MHz}$ and $125 \mathrm{MHz}$, respectively) and $\mathrm{CDCl}_{3}$ as solvent. Chemical shifts were recorded in parts per million (ppm) with internal reference to $\mathrm{CDCl}_{3}\left({ }^{1} \mathrm{H} \mathrm{NMR}\right.$ at $7.26 \mathrm{ppm},{ }^{13} \mathrm{C} \mathrm{NMR}$ at $\left.77.16 \mathrm{ppm}\right)$ and to $\left(\mathrm{CD}_{3}\right)_{2} \mathrm{CO}\left({ }^{1} \mathrm{H}\right.$ NMR at $2.05 \mathrm{ppm},{ }^{13} \mathrm{C}$ NMR at 29.84 and $\left.206.26 \mathrm{ppm}\right) .{ }^{19} \mathrm{~F}$ NMR spectra were obtained using a $500 \mathrm{MHz}$ NMR instrument (operating at $470 \mathrm{MHz}$ ) using trifluoroacetic acid (TFA, ${ }^{19} \mathrm{~F}$ NMR at -76.55 ppm vrs. $\mathrm{CFCl}_{3}$ ). Splitting patterns are indicated as follows: a, apparent, br, broad; s, singlet; d, doublet; t, triplet; q, quartet; m, multiplet. Coupling constants $(J)$ are reported in units of Hertz $(\mathrm{Hz})$. High and low resolution ESI+ mass spectra were recorded using ion trap instruments. Column chromatography was performed using 230-400 mesh ultrapure silica. TLC was performed using silica gel or neutral aluminum oxide plates and were visualised using UV light (254 nm) and/or developed with vanillin stain. UV analysis was carried out with the baseline manually corrected for the solvent used. Moisture-sensitive reactions were performed in flame-dried glassware under a positive pressure of nitrogen. Solutions of air- and moisture-sensitive compounds were introduced via syringe or cannula through a rubber septum. Compounds $4,^{45} \mathbf{9 ,},{ }^{46}$ and $\mathbf{1 5 ^ { 4 7 }}$ were prepared according to literature procedures.

\section{3-(4-(Carboxymethyl)-5-formyl-1H-pyrrol-3-yl)propanoic acid (8)}

Compound $4^{45}(0.050 \mathrm{~g}, 0.120 \mathrm{mmol})$ was added to a solution of $1 \mathrm{M} \mathrm{NaOH}$ in $1: 1 \mathrm{H}_{2} \mathrm{O} / \mathrm{MeOH}(1 \mathrm{~mL})$. The reaction mixture was heated to $50{ }^{\circ} \mathrm{C}$ until TLC analysis showed complete consumption of the starting material. The reaction mixture was diluted with $\mathrm{H}_{2} \mathrm{O}(50 \mathrm{~mL})$ and acidified to $\mathrm{pH} 4$ by use of $2 \mathrm{M}$ aq. $\mathrm{HCl}$ at $0{ }^{\circ} \mathrm{C}$. The reaction mixture was then extracted with $\mathrm{CH}_{2} \mathrm{Cl}_{2}(3 \times 50 \mathrm{~mL})$, and the combined organic fractions were washed with brine, dried over anhydrous $\mathrm{Na}_{2} \mathrm{SO}_{4}$, concentrated in 
vacuo and purified via column chromatography (50\% EtOAc/hexanes). The title compound was isolated as a white solid $(0.012 \mathrm{~g}, 27 \%$ yield $) .{ }^{1} \mathrm{H}\left(300 \mathrm{MHz}, \mathrm{C}(\mathrm{O})\left(\mathrm{CD}_{3}\right)_{2}\right): \delta 10.81(\mathrm{br} \mathrm{s}, 1 \mathrm{H}), 9.70(\mathrm{~s}$, 1H), 7.07 (as, 1H), $3.85(\mathrm{~s}, 2 \mathrm{H}), 2.78$ (t, $J=8.0 \mathrm{~Hz}$, expected $2 \mathrm{H}$ but overlaps with water peak), 2.59 (t, $J=8.0 \mathrm{~Hz}, 2 \mathrm{H})$ ppm; HRMS-ESI $(\mathrm{m} / z):[\mathrm{M}+\mathrm{Na}]^{+}$Calcd 248.0529 for $\mathrm{C}_{10} \mathrm{H}_{11} \mathrm{NNaO}_{5}$; found 248.0528.

${ }^{13} \mathrm{C} \mathrm{NMR}$ is not reported because of the instability of $\mathbf{8}$ in $\mathrm{CDCl}_{3}, \mathrm{C}(\mathrm{O})\left(\mathrm{CD}_{3}\right)_{2}$, and $\mathrm{CD}_{3} \mathrm{OD}$ for prolonged periods of time and its insolubility in THF- $d 8$ and $\mathrm{CD}_{3} \mathrm{CN}$.

\section{General Procedure (GP1) for Fluorination using XtalFluor ${ }^{\circledR}$}

XtalFluor-E ${ }^{\circledR}$ (3 equiv) or XtalFluor-M ${ }^{\circledR}$ (3 equiv) was added, as indicated, to a solution of $\mathrm{NEt}_{3} \cdot 3 \mathrm{HF}$ (4 equiv) and $\mathrm{NEt}_{3}$ (2 equiv) in 1,2-DCE [0.3 M], with stirring at room temperature under $\mathrm{N}_{2}$ atmosphere at $70{ }^{\circ} \mathrm{C}$. The 2-formylpyrrole substrate (1 equiv) was then added in one portion and the reaction mixture was stirred under $\mathrm{N}_{2}$ at room temperature overnight, before quenching with sat. aqueous $\mathrm{NaHCO}_{3}(10 \mathrm{~mL})$ and then stirring for 15 minutes. The reaction mixture was then diluted with $\mathrm{CH}_{2} \mathrm{Cl}_{2}(30 \mathrm{~mL})$ and washed with $\mathrm{H}_{2} \mathrm{O}(30 \mathrm{~mL})$ and brine $(30 \mathrm{~mL})$. The organic phase was dried over anhydrous $\mathrm{Na}_{2} \mathrm{SO}_{4}$, concentrated in vacuo and purified via column chromatography.

\section{2-(Difluoromethyl)-1-(phenylsulfonyl)-pyrrole (10)}

Using GP1 and XtalFluor-M ${ }^{\circledR}$ with gentle heating $\left(35^{\circ} \mathrm{C}\right)$ in $\mathrm{CH}_{2} \mathrm{Cl}_{2}$, the title compound was synthesised from 1-(phenylsulfonyl)-pyrrole-2-carbaldehyde $(9)^{46}(0.13 \mathrm{~g}, 0.57 \mathrm{mmol})$. The title compound was isolated as a white solid $(0.13 \mathrm{~g}$, 92\% yield) after column chromatography (10\% $\mathrm{Et}_{2} \mathrm{O} /$ hexanes). M.p.: $64-66{ }^{\circ} \mathrm{C} ;{ }^{1} \mathrm{H}$ NMR $\left(\mathrm{CDCl}_{3}, 500 \mathrm{MHz}\right): \delta 7.89(\mathrm{~d}, 2 \mathrm{H}, J=8.0 \mathrm{~Hz}), 7.63(\mathrm{t}, 1 \mathrm{H}, J$ $=8.0 \mathrm{~Hz}), 7.53(\mathrm{t}, 2 \mathrm{H}, J=8.0 \mathrm{~Hz}), 7.32(\mathrm{br} \mathrm{s}, 1 \mathrm{H}), 7.12\left(\mathrm{t}, 1 \mathrm{H}, J_{H F}=55 \mathrm{~Hz}, \mathrm{CF}_{2} \mathbf{H}\right), 6.66(\mathrm{br} \mathrm{s}, 1 \mathrm{H})$, $6.31($ at, $1 \mathrm{H}, J=1.8 \mathrm{~Hz}) \mathrm{ppm} ;{ }^{19} \mathrm{~F} \mathrm{NMR}\left(\mathrm{CDCl}_{3}, 470 \mathrm{MHz}\right) \delta-110.8\left(\mathrm{~d}, J_{F H}=55.0 \mathrm{~Hz}, \mathrm{CF} \mathbf{F}_{2} \mathrm{H}\right) \mathrm{ppm}$; ${ }^{13} \mathrm{C}\left\{{ }^{1} \mathrm{H}\right\} \mathrm{NMR}\left(\mathrm{CDCl}_{3}, 125 \mathrm{MHz}\right): \delta 138.6,134.5,129.6,127.9,127.4,125.1\left(\mathrm{t}, J_{C F}=3.0 \mathrm{~Hz}\right), 115.6$ 
$\left(\mathrm{t}, J_{C F}=5.0 \mathrm{~Hz}\right), 112.2,108.9\left(\mathrm{t}, J_{C F}=233 \mathrm{~Hz}, \mathrm{CF}_{2} \mathrm{H}\right) \mathrm{ppm} ; \operatorname{HRMS}-\mathrm{ESI}(\mathrm{m} / \mathrm{z}):[\mathrm{M}+\mathrm{Na}]^{+}$calcd 280.0214 for $\mathrm{C}_{11} \mathrm{H}_{9} \mathrm{~F}_{2} \mathrm{NNaO}_{2} \mathrm{~S}$; found 280.0201.

\section{(2-Nitrophenyl)(phenyl) sulfide (14)}

A solution of $\mathrm{PhSH}(0.30 \mathrm{~mL}, 3.21 \mathrm{mmol})$ and 1-(2-nitrophenylsulfonyl)-1H-pyrrole-2-carbaldehyde $(\mathbf{1 5})^{47}(0.50 \mathrm{~g}, 1.78 \mathrm{mmol})$ in anhydrous $\mathrm{CH}_{3} \mathrm{CN}(89 \mathrm{~mL})$ was bubbled with $\mathrm{N}_{2}$ for 10 minutes, after which anhydrous $\mathrm{NEt}_{3}(0.62 \mathrm{~mL}, 4.46 \mathrm{mmol})$ was added under $\mathrm{N}_{2}$. The reaction mixture was stirred for 30 minutes before the solvent was removed in vacuo. The crude residue was then dissolved in $\mathrm{CH}_{2} \mathrm{Cl}_{2}$ $(200 \mathrm{~mL})$ and washed with brine $(200 \mathrm{~mL})$. The organic layer was dried over $\mathrm{Na}_{2} \mathrm{SO}_{4}$, concentrated in vacuo and purified via column chromatography $\left(0 \rightarrow 5 \%\right.$ EtOAc/ $\left.\mathrm{CH}_{2} \mathrm{Cl}_{2}\right)$. The title compound was isolated as a yellow solid (0.41 g, quant.). M.p.: $69-70{ }^{\circ} \mathrm{C} ;{ }^{1} \mathrm{H}\left(500 \mathrm{MHz}, \mathrm{CDCl}_{3}\right): \delta 8.21(\mathrm{~d}, 1 \mathrm{H}, J=8.0$ $\mathrm{Hz}), 7.59-7.51(\mathrm{~m}, 2 \mathrm{H}), 7.50-7.46(\mathrm{~m}, 3 \mathrm{H}), 7.33(\mathrm{t}, 1 \mathrm{H}, J=8.0 \mathrm{~Hz}), 7.21(\mathrm{t}, 1 \mathrm{H}, J=8.0 \mathrm{~Hz}), 6.87(\mathrm{~d}$,

$1 \mathrm{H}, J=8.0 \mathrm{~Hz})$, comparable to previously reported data; ${ }^{48}{ }^{13} \mathrm{C}\left\{{ }^{1} \mathrm{H}\right\}: \mathrm{NMR}\left(\mathrm{CDCl}_{3}, 125 \mathrm{MHz}\right): \delta 145.2$, 139.5, 136.0, 133.5, 131.2, 130.2, 130.1, 128.5, 125.8, 125.1 ppm; HRMS-ESI $(\mathrm{m} / \mathrm{z}):[\mathrm{M}+\mathrm{Na}]^{+}$calcd 254.0246 for $\mathrm{C}_{12} \mathrm{H}_{9} \mathrm{NNaO}_{2} \mathrm{~S}$; found 254.0239; $\varepsilon_{368 \mathrm{~nm}}=4000 \mathrm{~L} \mathrm{~mol}^{-1} \mathrm{~cm}^{-1}$ in $\mathrm{CH}_{3} \mathrm{CN}$.

\section{2-(Difluoromethyl)-1-(2-nitrophenylsulfonyl)-4-(4-(trifluoromethyl)phenyl)-pyrrole (19a)}

Using GP1 and XtalFluor-M ${ }^{\circledR}$, the title compound was synthesised from 21a $(0.32 \mathrm{~g}, 0.75 \mathrm{mmol})$. The title compound was isolated as a beige solid $(0.29 \mathrm{~g}, 85 \%$ yield $)$ after column chromatography (50\% $\mathrm{CH}_{2} \mathrm{Cl}_{2}$ /hexanes). M.p.: 80-81 ${ }^{\circ} \mathrm{C} ;{ }^{1} \mathrm{H}$ NMR $\left(\mathrm{CDCl}_{3}, 500 \mathrm{MHz}\right): \delta 7.88(\mathrm{ad}, 1 \mathrm{H}), 7.80-7.84(\mathrm{~m}, 1 \mathrm{H})$, 7.71-7.76 (m, 3H), 7.64-7.67 (m, 4H), $7.09(\mathrm{~s}, 1 \mathrm{H}), 7.08\left(\mathrm{t}, 1 \mathrm{H}, J_{H F}=55 \mathrm{~Hz}, \mathrm{CF}_{2} \mathbf{H}\right) \mathrm{ppm} ;{ }^{19} \mathrm{~F} \mathrm{NMR}$ $\left(\mathrm{CDCl}_{3}, 470 \mathrm{MHz}\right) \delta-63.7(\mathrm{~s}),-113.1\left(\mathrm{~d}, J_{F H}=55 \mathrm{~Hz}, \mathrm{CF}_{2} \mathrm{H}\right) \mathrm{ppm} ;{ }^{13} \mathrm{C}\left\{{ }^{1} \mathrm{H}\right\} \mathrm{NMR}\left(\mathrm{CDCl}_{3}, 125 \mathrm{MHz}\right)$ $\delta 147.9,135.8,135.6,133.1,132.5,130.3,129.8\left(\mathrm{q}, J_{C F}=27 \mathrm{~Hz}\right), 126.3\left(\mathrm{q}, J_{C F}=256 \mathrm{~Hz}, \mathbf{C F}_{3}\right), 126.2$ $\left(\mathrm{aq}, J_{C F}=3.0 \mathrm{~Hz}\right), 126.1,125.5,122.6,114.3\left(\mathrm{t}, J_{C F}=5.0 \mathrm{~Hz}\right), 108.7\left(\mathrm{t}, J_{C F}=235 \mathrm{~Hz}, \mathbf{C F}_{2} \mathrm{H}\right) \mathrm{ppm}$, two 
carbon signals missing; HRMS-ESI $(m / z)$ : $[\mathrm{M}+\mathrm{Na}]^{+}$calcd 469.0257 for $\mathrm{C}_{18} \mathrm{H}_{11} \mathrm{~F}_{5} \mathrm{~N}_{2} \mathrm{NaO}_{4} \mathrm{~S}$; found 469.0241 .

\section{2-(Difluoromethyl)-4-(4-fluorophenyl)-1-(2-nitrophenylsulfonyl)-pyrrole (19b)}

Using GP1 and Xtalfluor- $\mathrm{E}^{\circledR}$, the title compound was synthesised from $\mathbf{2 1 b}(0.29 \mathrm{~g}, 0.78 \mathrm{mmol})$. The title compound was isolated as a beige solid $(0.19 \mathrm{~g}, 61 \%$ yield $)$ after column chromatography $(50 \%$ $\mathrm{CH}_{2} \mathrm{Cl}_{2}$ /hexanes). M.p.: $86-88{ }^{\circ} \mathrm{C} ;{ }^{1} \mathrm{H}$ NMR $\left(\mathrm{CDCl}_{3}, 500 \mathrm{MHz}\right): \delta 7.88(\mathrm{~d}, 1 \mathrm{H}, J=8.0 \mathrm{~Hz}), 7.80(\mathrm{t}, 1 \mathrm{H}$, $J=8.0 \mathrm{~Hz}), 7.71(\mathrm{t}, 1 \mathrm{H}, J=8.0 \mathrm{~Hz}), 7.63(\mathrm{~d}, 1 \mathrm{H}, J=8.0 \mathrm{~Hz}), 7.59(\mathrm{~d}, 1 \mathrm{H}, J=1.8 \mathrm{~Hz}), 7.49-7.52(\mathrm{~m}$,

2H), $7.09(\mathrm{t}, 2 \mathrm{H}, J=9.0 \mathrm{~Hz}), 7.06\left(\mathrm{t}, 1 \mathrm{H}, J_{H F}=55 \mathrm{~Hz}, \mathrm{CF}_{2} \mathbf{H}\right), 7.02(\mathrm{~s}, 1 \mathrm{H}) \mathrm{ppm} ;{ }^{19} \mathrm{~F} \mathrm{NMR}\left(\mathrm{CDCl}_{3}, 470\right.$ $\mathrm{MHz}) \delta-113.0\left(\mathrm{~d}, J_{F H}=55 \mathrm{~Hz}, \mathrm{CF}_{2} \mathrm{H}\right),-(115.0-115.1)(\mathrm{m}) \mathrm{ppm} ;{ }^{13} \mathrm{C}\left\{{ }^{1} \mathrm{H}\right\} \mathrm{NMR}\left(\mathrm{CDCl}_{3}, 125 \mathrm{MHz}\right): \delta$ $162.6\left(\mathrm{~d}, J_{C F}=248 \mathrm{~Hz}, \mathrm{CF}\right), 147.8,135.4,133.1,132.8,130.0,129.4,128.3\left(\mathrm{~d}, J_{C F}=3.0 \mathrm{~Hz}\right), 127.6(\mathrm{~d}$, $\left.J_{C F}=8.0 \mathrm{~Hz}\right), 126.8,125.4,121.4,116.1\left(\mathrm{~d}, J_{C F}=22 \mathrm{~Hz}\right), 114.6\left(\mathrm{t}, J_{C F}=5.0 \mathrm{~Hz}\right), 108.8\left(\mathrm{t}, J_{C F}=235\right.$ $\left.\mathrm{Hz}, \mathrm{CF}_{2} \mathrm{H}\right)$ ppm; HRMS-ESI $(\mathrm{m} / \mathrm{z})$ : $[\mathrm{M}+\mathrm{Na}]^{+}$calcd 419.0289 for $\mathrm{C}_{17} \mathrm{H}_{11} \mathrm{~F}_{3} \mathrm{~N}_{2} \mathrm{NaO}_{4} \mathrm{~S}$; found 419.0287.

\section{2-(Difluoromethyl)-1-(2-nitrophenylsulfonyl)-4-phenyl-1H-pyrrole (19c)}

Using GP1 and Xtalfluor-E ${ }^{\circledR}$, the title compound was synthesised from 21c $(0.23 \mathrm{~g}, 0.65 \mathrm{mmol})$. The title compound was isolated as a beige solid ( $0.22 \mathrm{~g}, 90 \%$ yield) after column chromatography $(50 \%$ $\mathrm{CH}_{2} \mathrm{Cl}_{2}$ /hexanes). M.p.: 100-103 ${ }^{\circ} \mathrm{C} ;{ }^{1} \mathrm{H} \mathrm{NMR}\left(\mathrm{CDCl}_{3}, 500 \mathrm{MHz}\right): \delta 7.89(\mathrm{~d}, 1 \mathrm{H}, J=8.0 \mathrm{~Hz}), 7.79(\mathrm{t}$, $1 \mathrm{H}, J=8.0 \mathrm{~Hz}), 7.70(\mathrm{t}, 1 \mathrm{H}, J=8.0 \mathrm{~Hz}), 7.65(\mathrm{as}, 1 \mathrm{H}), 7.54-7.57(\mathrm{~m}, 3 \mathrm{H}), 7.41(\mathrm{t}, 2 \mathrm{H}, J=8.0 \mathrm{~Hz})$, $7.32(\mathrm{t}, 1 \mathrm{H}, J=7.0 \mathrm{~Hz}), 7.09(\mathrm{~s}, 1 \mathrm{H}), 7.07\left(\mathrm{t}, 1 \mathrm{H}, J_{H F}=55 \mathrm{~Hz}, \mathrm{CF}_{2} \mathbf{H}\right) \mathrm{ppm} ;{ }^{19} \mathrm{~F} \mathrm{NMR}\left(\mathrm{CDCl}_{3}, 470\right.$ $\mathrm{MHz}) \delta-113.0\left(\mathrm{~d}, J_{F H}=55 \mathrm{~Hz}, \mathrm{CF} 2 \mathrm{H}\right) \mathrm{ppm} ;{ }^{13} \mathrm{C}\left\{{ }^{1} \mathrm{H}\right\} \mathrm{NMR}\left(\mathrm{CDCl}_{3}, 125 \mathrm{MHz}\right): \delta 135.3,133.1,133.0$, $129.8,129.4,129.2,128.0,127.7,125.9,125.4,121.6,114.7\left(\mathrm{t}, J_{C F}=5.0 \mathrm{~Hz}\right), 108.8\left(\mathrm{t}, J_{C F}=235 \mathrm{~Hz}\right.$, $\left.\mathrm{CF}_{2} \mathrm{H}\right)$ ppm $2 \mathrm{C}$ missing; HRMS-ESI $(\mathrm{m} / \mathrm{z}):[\mathrm{M}+\mathrm{H}]^{+}$calcd 379.0564 for $\mathrm{C}_{17} \mathrm{H}_{13} \mathrm{~F}_{2} \mathrm{~N}_{2} \mathrm{O}_{4} \mathrm{~S}$; found 379.0544 . 


\section{2-(Difluoromethyl)-1-(2-nitrophenylsulfonyl)-4-p-tolyl-1H-pyrrole (19d)}

Using GP1 and Xtalfluor- $\mathrm{E}^{\circledR}$, the title compound was synthesised from 21d $(0.24 \mathrm{~g}, 0.65 \mathrm{mmol})$. The title compound was isolated as a beige solid ( $0.18 \mathrm{~g}, 70 \%$ yield) after column chromatography $(50 \%$ $\mathrm{CH}_{2} \mathrm{Cl}_{2}$ /hexanes). M.p.: $114-115{ }^{\circ} \mathrm{C} ;{ }^{1} \mathrm{H} \mathrm{NMR}\left(\mathrm{CDCl}_{3}, 500 \mathrm{MHz}\right): \delta 7.88(\mathrm{~d}, 1 \mathrm{H}, J=8.0 \mathrm{~Hz}), 7.78(\mathrm{t}$, $1 \mathrm{H}, J=8.0 \mathrm{~Hz}) .7 .69(\mathrm{t}, 1 \mathrm{H}, J=8.0 \mathrm{~Hz}), 7.61(\mathrm{~d}, 1 \mathrm{H}, J=1.8 \mathrm{~Hz}), 7.53(\mathrm{~d}, 1 \mathrm{H}, J=8.0 \mathrm{~Hz}), 7.43(\mathrm{~d}, 2 \mathrm{H}$, $J=8.0 \mathrm{~Hz}), 7.21(\mathrm{~d}, 2 \mathrm{H}, J=8.0 \mathrm{~Hz}), 7.06(\mathrm{~s}, 1 \mathrm{H}), 7.06\left(\mathrm{t}, 1 \mathrm{H}, J_{H F}=55 \mathrm{~Hz}, \mathrm{CF}_{2} \mathbf{H}\right), 2.37(\mathrm{~s}, 3 \mathrm{H}) \mathrm{ppm}$;

${ }^{19} \mathrm{~F} \mathrm{NMR}\left(\mathrm{CDCl}_{3}, 470 \mathrm{MHz}\right) \delta-113.0\left(\mathrm{~d}, J_{F H}=55 \mathrm{~Hz}, \mathrm{CF}_{2} \mathrm{H}\right) \mathrm{ppm} ;{ }^{13} \mathrm{C}\left\{{ }^{1} \mathrm{H}\right\} \mathrm{NMR}\left(\mathrm{CDCl}_{3}, 125 \mathrm{MHz}\right)$ : $\delta 137.9,135.2,133.1,129.8,129.7,129.3,129.2,127.8,125.8,125.4,121.3,114.7\left(\mathrm{t}, J_{C F}=5.0 \mathrm{~Hz}\right)$, $108.8\left(\mathrm{t}, J_{C F}=235 \mathrm{~Hz}, \mathrm{CF}_{2} \mathrm{H}\right), 21.3 \mathrm{ppm}$, two carbon signals missing; HRMS-ESI $(\mathrm{m} / z):[\mathrm{M}+\mathrm{Na}]^{+}$ calcd 415.0540 for $\mathrm{C}_{18} \mathrm{H}_{14} \mathrm{~F}_{2} \mathrm{~N}_{2} \mathrm{NaO}_{4} \mathrm{~S}$; found 415.0522 .

\section{2-(Difluoromethyl)-4-(4-methoxyphenyl)-1-(2-nitrophenylsulfonyl)-1H-pyrrole (19e)}

Using GP1 and Xtalfluor-E ${ }^{\circledR}$, the title compound was synthesised from 21e $(0.30 \mathrm{~g}, 0.78 \mathrm{mmol})$. The title compound was isolated as a beige solid $(0.20 \mathrm{~g}, 62 \%$ yield $)$ after column chromatography $(50 \%$ $\mathrm{CH}_{2} \mathrm{Cl}_{2}$ /hexanes). M.p.: $145-148{ }^{\circ} \mathrm{C} ;{ }^{1} \mathrm{H} \mathrm{NMR}\left(\mathrm{CDCl}_{3}, 500 \mathrm{MHz}\right): \delta 7.88(\mathrm{~d}, 1 \mathrm{H} J=8.0 \mathrm{~Hz}), 7.78(\mathrm{t}$, $1 \mathrm{H}, J=8.0 \mathrm{~Hz}), 7.69(\mathrm{t}, 1 \mathrm{H}, J=8.0 \mathrm{~Hz}), 7.56(\mathrm{~d}, 1 \mathrm{H}, J=1.8 \mathrm{~Hz}), 7.53(\mathrm{~d}, 1 \mathrm{H}, J=8.0 \mathrm{~Hz}), 7.46(\mathrm{~d}, 2 \mathrm{H}$, $J=9.0 \mathrm{~Hz}), 7.07\left(\mathrm{t}, 1 \mathrm{H}, J_{H F}=55 \mathrm{~Hz}, \mathrm{CF}_{2} \mathrm{H}\right), 7.03(\mathrm{~s}, 1 \mathrm{H}), 6.94(\mathrm{~d}, 2 \mathrm{H}, J=9.0 \mathrm{~Hz}), 3.84(\mathrm{~s}, 3 \mathrm{H}) \mathrm{ppm}$;

${ }^{19} \mathrm{~F} \mathrm{NMR}\left(\mathrm{CDCl}_{3}, 470 \mathrm{MHz}\right) \delta-113.0\left(\mathrm{~d}, J_{F H}=55 \mathrm{~Hz}, \mathrm{CF}_{2} \mathrm{H}\right) \mathrm{ppm} ;{ }^{13} \mathrm{C}\left\{{ }^{1} \mathrm{H}\right\}: \mathrm{NMR}\left(\mathrm{CDCl}_{3}, 125\right.$ MHz): $\delta 159.6,147.7,135.2,133.1,129.6,129.3,129.1,127.5,127.1,125.4,124.7,120.7,114.7\left(\mathrm{t}, J_{C F}\right.$ $=5.0 \mathrm{~Hz}), 114.6,108.8\left(\mathrm{t}, J_{C F}=235 \mathrm{~Hz}, \mathrm{CF}_{2} \mathrm{H}\right), 55.5 \mathrm{ppm} ; \operatorname{HRMS}-\mathrm{ESI}(\mathrm{m} / \mathrm{z}):[\mathrm{M}+\mathrm{Na}]^{+}$calcd 431.0489 for $\mathrm{C}_{18} \mathrm{H}_{14} \mathrm{~F}_{2} \mathrm{~N}_{2} \mathrm{NaO}_{5} \mathrm{~S}$; found 431.0491 .

\section{2-(Difluoromethyl)-4-(4-cyanophenyl)-1-(2-nitrophenylsulfonyl)-1H-pyrrole (19f)}

Using GP1 and Xtalfluor- $\mathrm{E}^{\circledR}$, the title compound was synthesised from $21 \mathbf{f}(0.13 \mathrm{~g}, 0.33 \mathrm{mmol})$. The title compound was isolated as a beige solid ( $0.12 \mathrm{~g}, 86 \%$ yield) after column chromatography $(90 \%$ 
$\mathrm{CH}_{2} \mathrm{Cl}_{2}$ /hexanes). M.p.: $171-173{ }^{\circ} \mathrm{C} ;{ }^{1} \mathrm{H}$ NMR $\left(\mathrm{CDCl}_{3}, 500 \mathrm{MHz}\right): \delta 7.88(\mathrm{~d}, 1 \mathrm{H} J=8.0 \mathrm{~Hz}), 7.81-7.85$ $(\mathrm{m}, 1 \mathrm{H}), 7.74-7.80(\mathrm{~m}, 3 \mathrm{H}), 7.69(\mathrm{~d}, 1 \mathrm{H}, J=8.3 \mathrm{~Hz}), 7.64(\mathrm{~d}, 2 \mathrm{H}, J=8.3 \mathrm{~Hz}), 7.07\left(\mathrm{t}, 1 \mathrm{H}, J_{H F}=55 \mathrm{~Hz}\right.$, $\left.\mathrm{CF}_{2} \mathrm{H}\right), 7.07(\mathrm{~s}, 1 \mathrm{H}) \mathrm{ppm} ;{ }^{19} \mathrm{~F} \mathrm{NMR}\left(\mathrm{CDCl}_{3}, 470 \mathrm{MHz}\right) \delta-112.0\left(\mathrm{~d}, J_{F H}=55 \mathrm{~Hz}, \mathrm{C} \mathbf{F}_{2} \mathrm{H}\right) \mathrm{ppm} ;{ }^{13} \mathrm{C}\left\{{ }^{1} \mathrm{H}\right\}$ : $\operatorname{NMR}\left(\mathrm{CDCl}_{3}, 125 \mathrm{MHz}\right): \delta 147.9,136.8,135.8,133.1,133.0,132.2,130.6,129.7\left(\mathrm{t}, J_{C F}=31.5 \mathrm{~Hz}\right)$, $126.3,125.6,125.5,123.1,118.8,114.1\left(\mathrm{t}, J_{C F}=5.0 \mathrm{~Hz}\right), 111.4,108.6\left(\mathrm{t}, J_{C F}=235 \mathrm{~Hz}, \mathbf{C F}_{2} \mathrm{H}\right) \mathrm{ppm}$; HRMS-ESI $(m / z):[\mathrm{M}+\mathrm{Na}]^{+}$calcd 426.0331 for $\mathrm{C}_{18} \mathrm{H}_{11} \mathrm{~F}_{2} \mathrm{~N}_{3} \mathrm{NaO}_{4} \mathrm{~S}$; found 426.0341 .

\section{4-Bromo-1-(2-nitrophenylsulfonyl)-pyrrole-2-carbaldehyde (20)}

4-Bromo-2-formyl pyrrole ${ }^{49}$ (2.72 g, $\left.15.6 \mathrm{mmol}\right)$, 2-nitrobenzenesulfonylchloride (3.15 g, $\left.14.2 \mathrm{mmol}\right)$ and $\mathrm{NEt}_{3}(2.97 \mathrm{~mL}, 21.3 \mathrm{mmol})$ were dissolved in $\mathrm{CH}_{2} \mathrm{Cl}_{2}(55 \mathrm{~mL})$. Dimethylaminopyridine $(0.17 \mathrm{~g}$, $1.42 \mathrm{mmol}$ ) was added to the stirring reaction mixture, and the solution was stirred overnight. The reaction mixture was washed with $\mathrm{H}_{2} \mathrm{O}(60 \mathrm{~mL})$ and brine $(60 \mathrm{~mL})$. The organic layer was dried over $\mathrm{Na}_{2} \mathrm{SO}_{4}$, concentrated in vacuo and purified via column chromatography $\left(50 \% \mathrm{CH}_{2} \mathrm{Cl}_{2} /\right.$ hexanes $)$. The title compound was isolated as an off-white solid (4.17 g, 82\% yield). M.p.: $143-145{ }^{\circ} \mathrm{C} ;{ }^{1} \mathrm{H}$ NMR $\left(\mathrm{CDCl}_{3}, 500 \mathrm{MHz}\right): \delta 9.57(\mathrm{~s}, 1 \mathrm{H}), 8.47-8.49(\mathrm{~m}, 1 \mathrm{H}), 7.83-7.85(\mathrm{~m}, 3 \mathrm{H}), 7.71(\mathrm{~s}, 1 \mathrm{H}), 7.16(\mathrm{~s}, 1 \mathrm{H})$ ppm; ${ }^{13} \mathrm{C}\left\{{ }^{1} \mathrm{H}\right\} \mathrm{NMR}\left(\mathrm{CDCl}_{3}, 125 \mathrm{MHz}\right): \delta 176.9,148.2,136.0,133.8,133.5,132.7,131.1,130.7$, 129.5, 125.3, 100.9 ppm; HRMS-ESI $(m / z):[\mathrm{M}+\mathrm{H}]^{+}$calcd 358.9337 for $\mathrm{C}_{11} \mathrm{H}_{8} \mathrm{BrN}_{2} \mathrm{O}_{5} \mathrm{~S}$; found 358.9325 .

\section{General Procedure (GP2) for the Suzuki Cross-Coupling of 4-Bromopyrroles}

4-Bromo-1-(2-nitrophenylsulfonyl)-pyrrole-2-carbaldehyde (20) (1 equiv) was dissolved in toluene [0.1 M], along with a boronic acid a-e (1.2 equiv) and $\mathrm{Pd}\left(\mathrm{PPh}_{3}\right)_{4}\left(0.1\right.$ equiv) under $\mathrm{N}_{2}$ atmosphere with stirring. $\mathrm{K}_{2} \mathrm{CO}_{3}$ (4 equiv) was prepared as an aqueous solution [1.1 M], and then purged with $\mathrm{N}_{2}$ for 15 minutes. The $\mathrm{K}_{2} \mathrm{CO}_{3}$ aqueous solution was then added to the stirring reaction mixture, which was subsequently heated with stirring at $90{ }^{\circ} \mathrm{C}$ overnight. The reaction mixture was then partitioned and the 
aqueous layer was extracted with $\mathrm{CH}_{2} \mathrm{Cl}_{2}$ (equivalent volume to aqueous layer $\mathrm{x} 3$ ). The combined organic layers were dried over $\mathrm{Na}_{2} \mathrm{SO}_{4}$, filtered, concentrated in vacuo and then purified via column chromatography.

\section{1-(2-Nitrophenylsulfonyl)-4-(4-(trifluoromethyl)phenyl)-pyrrole-2-carbaldehyde (21a)}

Using GP2 and 4-(trifluoromethyl)phenylboronic acid, the title compound was synthesised from 20 $(0.50 \mathrm{~g}, 1.39 \mathrm{mmol})$. The title compound was isolated as an off-white solid $(0.36 \mathrm{~g}, 62 \%$ yield $)$ after column chromatography $\left(\mathrm{CH}_{2} \mathrm{Cl}_{2}\right)$. M.p.: $187-189{ }^{\circ} \mathrm{C} ;{ }^{1} \mathrm{H} \mathrm{NMR}\left(\mathrm{CDCl}_{3}, 500 \mathrm{MHz}\right): \delta 9.70(\mathrm{~s}, 1 \mathrm{H})$, 8.56-8.60 (m, 1H), $8.03(\mathrm{~s}, 1 \mathrm{H}), 7.85-7.88(\mathrm{~m}, 3 \mathrm{H}), 7.68-7.72(\mathrm{~m}, 4 \mathrm{H}), 7.49(\mathrm{~d}, 1 \mathrm{H}, J=2.0 \mathrm{~Hz}) \mathrm{ppm}$;

${ }^{19} \mathrm{~F}$ NMR $\left(\mathrm{CDCl}_{3}, 470 \mathrm{MHz}\right) \delta-62.6(\mathrm{~s}) \mathrm{ppm} ;{ }^{13} \mathrm{C}\left\{{ }^{1} \mathrm{H}\right\} \mathrm{NMR}\left(\mathrm{CDCl}_{3}, 125 \mathrm{MHz}\right): \delta 177.3,176.9$, $148.3,135.9,135.4,134.2,133.9,132.6,131.2,130.1\left(\mathrm{q}, J_{C F}=33 \mathrm{~Hz}\right), 128.3,126.3\left(\mathrm{q}, J_{C F}=270 \mathrm{~Hz}\right.$, $\left.\mathrm{CF}_{3}\right), 126.2\left(\mathrm{ad} J_{C F}=3.5 \mathrm{~Hz}\right), 126.2,125.8,125.3 \mathrm{ppm} ; \mathrm{HRMS}-\mathrm{ESI}(\mathrm{m} / \mathrm{z}):[\mathrm{M}+\mathrm{Na}]^{+}$calcd 447.0238 for $\mathrm{C}_{18} \mathrm{H}_{11} \mathrm{~F}_{3} \mathrm{~N}_{2} \mathrm{NaO}_{5} \mathrm{~S}$; found 447.0235.

\section{4-(4-Fluorophenyl)-1-(2-nitrophenylsulfonyl)-pyrrole-2-carbaldehyde (21b)}

Using GP2 and 4-fluorophenylboronic acid, the title compound was synthesised from 20 (0.50 g, 1.39 mmol). The title compound was isolated as an off-white solid (0.45 g, 86\% yield) after column chromatography $\left(\mathrm{CH}_{2} \mathrm{Cl}_{2}\right)$. M.p.: $172-175{ }^{\circ} \mathrm{C} ;{ }^{1} \mathrm{H}_{\mathrm{NMR}}\left(\mathrm{CDCl}_{3}, 500 \mathrm{MHz}\right): \delta 9.68(\mathrm{~s}, 1 \mathrm{H}), 8.51-8.53$ (m, 1H), $7.90(\mathrm{~s}, 1 \mathrm{H}), 7.83-7.85(\mathrm{~m}, 3 \mathrm{H}), 7.53-7.55(\mathrm{~m}, 2 \mathrm{H}), 7.42(\mathrm{~d}, 1 \mathrm{H}, J=2.0 \mathrm{~Hz}), 7.12(\mathrm{t}, 2 \mathrm{H}, J=$ $9.0 \mathrm{~Hz}) \mathrm{ppm} ;{ }^{19} \mathrm{~F} \mathrm{NMR}\left(\mathrm{CDCl}_{3}, 470 \mathrm{MHz}\right) \delta-(113.6-113.7)(\mathrm{m}) \mathrm{ppm} ;{ }^{13} \mathrm{C}\left\{{ }^{1} \mathrm{H}\right\} \mathrm{NMR}\left(\mathrm{CDCl}_{3}, 125\right.$ MHz): $\delta 177.6,162.8\left(\mathrm{~d}, J_{C F}=248 \mathrm{~Hz}, \mathbf{C F}\right), 135.7,134.1,133.7,132.6,131.4,129.6,128.0\left(\mathrm{~d}, J_{C F}=\right.$ 3.0 Hz), $127.7\left(\mathrm{~d}, J_{C F}=8.0 \mathrm{~Hz}\right), 127.5,126.8,126.0,125.2,116.3\left(\mathrm{~d}, J_{C F}=22 \mathrm{~Hz}\right)$; HRMS-ESI $(m / z)$ : $[\mathrm{M}+\mathrm{Na}]^{+}$Calcd 397.0270 for $\mathrm{C}_{17} \mathrm{H}_{11} \mathrm{FN}_{2} \mathrm{NaO}_{5} \mathrm{~S}$; found 397.0271. 


\section{1-(2-Nitrophenylsulfonyl)-4-phenyl-pyrrole-2-carbaldehyde (21c)}

Using GP2 and phenylboronic acid, the title compound was synthesised from 20 (0.87 $\mathrm{g}, 2.78 \mathrm{mmol})$. The title compound was isolated as an off-white solid $(0.65 \mathrm{~g}, 66 \%$ yield $)$ after column chromatography $\left(\mathrm{CH}_{2} \mathrm{Cl}_{2}\right)$. M.p.: $177-178{ }^{\circ} \mathrm{C} ;{ }^{1} \mathrm{H} \mathrm{NMR}\left(\mathrm{CDCl}_{3}, 500 \mathrm{MHz}\right): \delta 9.69(\mathrm{~s}, 1 \mathrm{H}), 8.48-8.50$ (m, 1H), $7.96(\mathrm{~s}, 1 \mathrm{H}), 7.83(\mathrm{ad}, 3 \mathrm{H}), 7.58(\mathrm{~d}, 2 \mathrm{H}, J=8.0 \mathrm{~Hz}), 7.49(\mathrm{~s}, 1 \mathrm{H}), 7.43(\mathrm{t}, 2 \mathrm{H}, J=8.0 \mathrm{~Hz})$, $7.34(\mathrm{t}, 1 \mathrm{H}, J=7.0 \mathrm{~Hz}) \mathrm{ppm} ;{ }^{13} \mathrm{C}\left\{{ }^{1} \mathrm{H}\right\} \mathrm{NMR}\left(\mathrm{CDCl}_{3}, 125 \mathrm{MHz}\right): \delta 177.7,135.7,134.1,133.5,132.6$, 131.7, 131.5, 129.3, 128.2, $127.7(\times 2 \mathrm{C}), 126.2,126.0,125.2 \mathrm{ppm}$, one carbon signal missing; HRMSESI $(m / z):[\mathrm{M}+\mathrm{H}]^{+}$calcd 357.0540 for $\mathrm{C}_{17} \mathrm{H}_{12} \mathrm{~N}_{2} \mathrm{NaO}_{5} \mathrm{~S}$; found 357.0553 .

\section{1-(2-Nitrophenylsulfonyl)-4-p-tolyl-pyrrole-2-carbaldehyde (21d)}

Using GP2 and 4-tolueneboronic acid, the title compound was synthesised from 20 (0.50 g, 1.39 mmol). The title compound was isolated as an off-white solid $(0.315 \mathrm{~g}, 61 \%$ yield $)$ after column chromatography $\left(\mathrm{CH}_{2} \mathrm{Cl}_{2}\right)$. M.p.: $171-172{ }^{\circ} \mathrm{C} ;{ }^{1} \mathrm{H} \mathrm{NMR}\left(\mathrm{CDCl}_{3}, 500 \mathrm{MHz}\right): \delta 9.68(\mathrm{~s}, 1 \mathrm{H}), 8.44-8.46$ $(\mathrm{m}, 1 \mathrm{H}), 7.92(\mathrm{~d}, 1 \mathrm{H}, J=1.0 \mathrm{~Hz}), 7.81-7.82(\mathrm{~m}, 3 \mathrm{H}), 7.47(\mathrm{~d}, 2 \mathrm{H}, J=8.0 \mathrm{~Hz}), 7.46(\mathrm{~s}, 1 \mathrm{H}), 7.23(\mathrm{~d}$, $2 \mathrm{H}, J=8.0 \mathrm{~Hz}), 2.38(\mathrm{~s}, 3 \mathrm{H}) \mathrm{ppm} ;{ }^{13} \mathrm{C}\left\{{ }^{1} \mathrm{H}\right\} \mathrm{NMR}\left(\mathrm{CDCl}_{3}, 125 \mathrm{MHz}\right): \delta 177.7,148.2,138.1,135.6$, 134.0, 133.4, 132.6, 131.6, 129.9, 128.8, 127.8, 127.3, 126.1, 125.9, 125.2, 21.3 ppm; HRMS-ESI $(m / z):[\mathrm{M}+\mathrm{Na}]^{+}$calcd 393.0521 for $\mathrm{C}_{18} \mathrm{H}_{14} \mathrm{~N}_{2} \mathrm{NaO}_{5} \mathrm{~S}$; found 393.0508 .

\section{4-(4-Methoxyphenyl)-1-(2-nitrophenylsulfonyl)-pyrrole-2-carbaldehyde (21e)}

Using GP2 and 4-methoxyphenylboronic acid, the title compound was synthesised from $20(0.50 \mathrm{~g}$, $1.39 \mathrm{mmol})$. The title compound was isolated as an off-white solid (0.35 $\mathrm{g}, 65 \%$ yield $)$ after column chromatography $\left(\mathrm{CH}_{2} \mathrm{Cl}_{2}\right)$. M.p.: $165-166{ }^{\circ} \mathrm{C} ;{ }^{1} \mathrm{H}$ NMR $\left(\mathrm{CDCl}_{3}, 500 \mathrm{MHz}\right): \delta 9.68(\mathrm{~s}, 1 \mathrm{H}), 8.43-8.45$ $(\mathrm{m}, 1 \mathrm{H}), 7.87(\mathrm{~s}, 1 \mathrm{H}), 7.80-7.82(\mathrm{~m}, 3 \mathrm{H}), 7.49(\mathrm{~d}, 2 \mathrm{H}, J=9.0 \mathrm{~Hz}), 7.43(\mathrm{~d}, 1 \mathrm{H}, J=2.0 \mathrm{~Hz}), 6.96(\mathrm{~d}$, $2 \mathrm{H}, J=9.0 \mathrm{~Hz}), 3.84(\mathrm{~s}, 3 \mathrm{H}) \mathrm{ppm} ;{ }^{13} \mathrm{C}\left\{{ }^{1} \mathrm{H}\right\} \mathrm{NMR}\left(\mathrm{CDCl}_{3}, 125 \mathrm{MHz}\right): \delta 177.7,159.7,148.2,135.6$, 
134.0, 133.3, 132.6, 131.6, 127.6, 127.2, 126.8, 126.0, 125.1, 124.3, 114.7, 55.5 ppm; HRMS-ESI $(m / z):[\mathrm{M}+\mathrm{Na}]^{+}$calcd 409.0470 for $\mathrm{C}_{18} \mathrm{H}_{14} \mathrm{~N}_{2} \mathrm{NaO}_{6} \mathrm{~S}$; found 409.0464 .

\section{4-(4-Cyanophenyl)-1-(2-nitrophenylsulfonyl)-pyrrole-2-carbaldehyde (21f)}

Using GP2 and 4-cyanophenylboronic acid, the title compound was synthesised from $20(0.25 \mathrm{~g}, 0.70$ mmol). The title compound was isolated as an off-white solid (0.085 $\mathrm{g}, 32 \%$ yield) after column chromatography $\left(\mathrm{CH}_{2} \mathrm{Cl}_{2}\right)$. M.p.: $195-197{ }^{\circ} \mathrm{C}$ with decomp.; ${ }^{1} \mathrm{H}$ NMR $\left(\mathrm{CDCl}_{3}, 500 \mathrm{MHz}\right): \delta 9.69(\mathrm{~s}$, $1 \mathrm{H}), 8.60-8.61(\mathrm{~m}, 1 \mathrm{H}), 8.04(\mathrm{~d}, 1 \mathrm{H}, J=1.4 \mathrm{~Hz}), 7.85-7.88(\mathrm{~m}, 3 \mathrm{H}), 7.73(\mathrm{~d}, 2 \mathrm{H}, J=8.3 \mathrm{~Hz}), 7.68(\mathrm{~d}$,

$2 \mathrm{H}, J=8.3 \mathrm{~Hz}), 7.48(\mathrm{~d}, 1 \mathrm{H}, J=1.4 \mathrm{~Hz}) \mathrm{ppm} ;{ }^{13} \mathrm{C}\left\{{ }^{1} \mathrm{H}\right\} \mathrm{NMR}\left(\mathrm{CDCl}_{3}, 125 \mathrm{MHz}\right): \delta 177.5,148.3$, $136.4,136.0,134.3,134.1,133.1,132.7,132.0,128.7,126.4,125.6,125.5,125.3,118,7,111.7$ ppm; HRMS-ESI $(m / z):[\mathrm{M}+\mathrm{Na}]^{+}$calcd 404.0312 for $\mathrm{C}_{18} \mathrm{H}_{11} \mathrm{~N}_{3} \mathrm{NaO}_{5} \mathrm{~S}$; found 404.0305 .

\section{Electronic Supplementary Information}

Data regarding rates of reaction; copies of NMR spectra. See DOI: XXX

\section{AUTHOR INFORMATION Corresponding Author}

*E-mail: Alison.Thompson@dal.ca

\section{Acknowledgments}

This work was supported by the Natural Sciences and Engineering Research Council of Canada (NSERC) and the Nova Scotia Health Research Foundation (NSHRF). The authors thank Professor Norman P. Schepp (Dalhousie University) for assistance as regards to determining rates of reaction.

\section{Notes and references}

(1) Lash, T. D.; Mani, U. N.; Drinan, M. A.; Zhen, C.; Hall, T.; Jones, M. A. J. Org. Chem 1999, 64, 464. 
(2) Lash, T. D.; Mani, U. N.; Lyons, E. A.; Thientanavanich, P.; Jones, M. A. J. Org. Chem 1999, $64,478$.

(3) Bachmann, J.; Nocera, D. G. J. Am. Chem. Soc 2005, 127, 4730.

(4) Benton, C. M.; Lim, C. K. Biomed. Chromatogr 2012, 26, 1009.

(5) Floriani, C. Chem. Commun 1996, 1257.

(6) Baeyer, A. Ber. Dtsch. Chem. Ges. 1886, 19, 2184.

(7) Gale, P. A. Coord. Chem. Rev 2001, 213, 79.

(8) Gale, P. A.; Anzenbacher Jr, P.; Sessler, J. L. Coord. Chem. Rev 2001, 222, 57.

(9) Gale, P. A. Acc. Chem. Res 2011, 44, 216.

(10) Mokhtari, B.; Pourabdollah, K. J. Incl. Phenom. Macrocycl. Chem 2013, 77, 23.

(11) Kim, S. K.; Sessler, J. L. Acc. Chem. Res 2014, 47, 2525.

(12) Kim, D. S.; Sessler, J. L. Chem. Soc. Rev 2015, 44, 532.

(13) Labuta, J.; Hill, J. P.; Ishihara, S.; Hanyková, L.; Ariga, K. Acc. Chem. Res 2015, 48, 521.

(14) Saha, I.; Lee, J. T.; Lee, C.-H. Eur. J. Org. Chem 2015, 2015, 3859.

(15) O'Hagan, D. Chem. Soc. Rev 2008, 37, 308.

(16) Jaunzems, J.; Braun, M. Org. Process Res. Dev. 2014, 18, 1055.

(17) O'Hagan, D. J. Flourine Chem. 2010, 131, 1071.

(18) Baumann, M.; Ian R. Baxendale, I. R.; Ley, S. V.; Nikbin, N. Beilstein J. Org. Chem. 2011, 7, 442.

(19) Fujiwara, Y.; Dixon, J. A.; Rodriguez, R. A.; Baxter, R. D.; Dixon, D.; Collins, M. R.; Blackmond, D. G.; Baran, P. S. J. Am. Chem. Soc. 2012, 134, 1494.

(20) Lin, X.; Weng, Z. Org. Biomol. Chem. 2015, 13, 3432.

(21) Levin, V. V.; Trifonov, A. L.; Zemtsov, A. A.; Struchkova, M. I.; Arkhipov, D. E.; Dilman, A. D. Org. Lett. 2014, 16, 6256.

(22) Ilchenko, N. O.; Tasch, B. O. A.; Szabó, K. J. Angew. Chem. Int. Ed. 2014, 53, 12897.

(23) Liang, T.; Neumann, C. N.; Ritter, T. Angew. Chem. Int. Ed. 2013, 52, 8214.

(24) Wang, J.; Stolowich, N. J.; Scott, A. I. Tetrahedron Lett. 1995, 36, 2389.

(25) Kondratov, I. S.; Dolovanyuk, V. G.; Tolmachova, N. A.; Gerus, I. I.; Bergander, K.; Frohlich, R.; Haufe, G. Org. Biomol. Chem. 2012, 10, 8778.

(26) Merrill, B. A.; LeGoff, E. The Journal of Organic Chemistry 1990, 55, 2904.

(27) Fukuyama, T.; Jow, C.-K.; Cheung, M. Tetrahedron Letters 1995, 36, 6373.

(28) Thompson, A.; Butler, R. J.; Grundy, M. N.; Laltoo, A. B. E.; Robertson, K. N.; Cameron, T. S. J. Org. Chem. 2005, 70, 3753.

(29) Jia, X.; Yu, L.; Liu, J.; Xu, Q.; Sickert, M.; Chena, L.; Lautens, M. Green Chem. 2014, 16, 3444.

(30) Fu, W.; Liu, T.; Fang, Z.; Ma, Y.; Zheng, X.; Wang, W.; Ni, X.; Hu, M.; Tang, T. Chem. Commun. 2015, 51, 5890.

(31) Guan, P.; Cao, C.; Liu, Y.; Li, Y.; He, P.; Chen, Q.; Liu, G.; Shi, Y. Tetrahedron Lett. 2012, 53, 5987.

(32) Garabatos-Perera, J. R.; Rotstein, B. H.; Thompson, A. J. Org. Chem 2007, 72, 7382.

(33) Castanheiro, T.; Gulea, M.; Donnard, M.; Suffert, J. Euro. J. Org. Chem. 2014, 7814.

(34) Jawale, D. V.; Gravel, E.; Geertsen, V.; Li, H.; Shah, N.; Namboothiri, I. N. N.; Doris, E. ChemCatChem 2014, 6, 719.

(35) Mauldin III, R. L.; Berndt, T.; Sipila, M.; Paasonen, P.; Petaja, T.; Kim, S.; Kurten, T.; Stratmann, F.; Kerminen, V. M.; Kulmala, M. Nature 2012, 488, 193.

(36) Hansch, C.; Leo, A.; Taft, R. W. Chem. Rev. 1991, 91, 165.

(37) Bordwell, F. G.; Hughes, D. L. J. Org. Chem. 1982, 47, 3224.

(38) Kolthoff, I. M.; Chantooni, M. K. J.; Bhowmik, S. J. Am. Chem. Soc. 1968, 90, 23. 
(39) Junttila, M. H.; Hormi, O. E. O. J. Org. Chem. 2007, 72, 2956.

(40) Hofstra, J. L.; Grassbaugh, B. R.; Tran, Q. M.; Armada, N. R.; de Lijser, H. J. P. J. Org. Chem. 2015, 80, 256.

(41) Bergeron, M.; Johnson, T.; Paquin, J. F. Angew. Chem. Int. Ed. 2011, 50, 11112.

(42) Thompson, A.; Gao, S.; Modzelewska, G.; Hughes, D. S.; Patrick, B.; Dolphin, D. Org. Lett 2000, 2, 3587.

(43) Schauder, J.-R.; Jendrezejewski, S.; L. Neidhart, W.; J. Hart, G.; R. Battersby, A. J. Chem. Soc., Perkin Trans. 1 1999, 2691.

(44) Abell, A. D.; Nabbs, B. K.; Battersby, A. R. J. Am. Chem Soc 1998, 120, 1741.

(45) Battersby, A. R.; Fookes, C. J. R.; Meegan, M. J.; McDonald, E.; Wurziger, H. K. W. J. Chem. Soc., Perkin Trans. 1 1981, 2786.

(46) Hinz, W.; Jones, R. A.; Anderson, T. Synthesis 1986, 620.

(47) Paulvannan, K. J. Org. Chem. 2004, 69, 1207.

(48) Goriya, Y.; Ramana, C. V. Tetrahedron 2010, 66, 7642.

(49) Krayer, M.; Balasubramanian, T.; Ruzié, C.; Ptaszek, M.; Cramer, D. L.; Taniguchi, M.; Lindsey, J. S. J. Porphyrins Phthalocyanines 2009, 13, 1098. 